\title{
Finishing Bedding Plants: A Comparison of an Unheated High Tunnel versus a Heated Greenhouse in Two Geographic Locations
}

\author{
Christopher J. Currey ${ }^{1,3}$, Roberto G. Lopez ${ }^{1,4,5}$, and \\ Neil S. Mattson ${ }^{2,4}$
}

ADDITIONAL INDEX WORDs. cool growing, daily light integral, herbaceous annuals, hoop house, temperature

SUMMARY. Energy accounts for one of the largest costs in commercial greenhouse (GH) production of annual bedding plants. Therefore, many bedding plant producers are searching for energy efficient production methods. Our objectives were to quantify the impact of growing annual bedding plants in an unheated high tunnel (HT) compared with a traditional heated GH environment at two northern latitudes. Ten popular bedding plants [angelonia (Angelonia angustifolia), vinca (Catharanthus roseus), celosia (Celosia argentea), dianthus (Dianthus chinensis), geranium (Pelargonium $\times$ hortorum), petunia $($ Petunia $\times$ bybrida), french marigold (Tagetes patula), viola (Viola $\times$ cornuta), snapdragon (Antirrbinum majus), and osteospermum (Osteospermum ecklonis)] were grown both in an unheated HT and a glass-glazed $\mathrm{GH}$ with an $18^{\circ} \mathrm{C}$ temperature set point beginning on $1 \mathrm{Apr} .2011$ at both Cornell University (Ithaca, NY) and Purdue University (West Lafayette, IN). Although seven of the species exhibited a delay in flowering in the HT as compared with the heated GH, there were no differences in days to flower (DTF) for geranium, osteospermum, and viola grown at Cornell and viola at Purdue. The remaining species exhibited delays in flowering in the HT environment, which varied based on species. At Purdue, several species were lost because of a cold temperature event necessitating a second planting. For the second planting, osteospermum was the only species grown that flowered significantly later in the HT; 7 days later than the GH-grown plants. Production of cold-tolerant annuals in unheated or minimally heated HTs appears to be a viable alternative for commercial producers aiming to reduce energy costs.

G reenhouse bedding plant production begins in mid-to-late winter and early spring in temperate northern latitudes when ambient outdoor air temperatures and photosynthetic daily light integrals (DLI) are at seasonally low levels. During this time, GHs are heated to maintain desirable production temperatures. The energy for

\footnotetext{
We gratefully acknowledge funding from growers providing support for Purdue University and Cornell University floriculture research, and support from the Purdue University and Cornell University Agricultural Experiment Station and from the Indiana Specialty Crop Block Grant 205749.

We thank C. Rakers \& Sons for plant material and Fafard Inc. for growing substrate.

The use of trade names in this publication does not imply endorsement by Purdue University or Cornell University of products named nor criticism of similar ones not mentioned.

${ }^{1}$ Department of Horticulture and Landscape Architecture, Purdue University, West Lafayette, IN 47907. 2010

${ }^{2}$ Department of Horticulture, Cornell University, Ithaca, NY 14853-5904

${ }^{3}$ Former graduate research assistant

${ }^{4}$ Associate professor and extension specialist

${ }^{5}$ Corresponding author. E-mail: rglopez@purdue.edu.
}

heating in northern climates accounts for $10 \%$ to $30 \%$ of the total operating costs of commercial GHs (Brumfield, 2007; Langton et al., 2006). Therefore, producers are seeking alternative bedding plant production strategies that reduce overall consumption of fuel.

Although HTs are not designed to be equivalent to $\mathrm{GHs}$ for yearround protected crop cultivation, there is potential for seasonal use in semiprotected crop cultivation. In floriculture, HTs are employed in cut flower production for season extension and frost protection (Armitage and Laushman, 2003; Byczynski,
2008; Lamont, 2009; Wien, 2009). HTs generally lack automated ventilation and are passively cooled through side- and/or end-wall and gable ventilation (Lamont, 2009). As a result, daytime air temperatures inside HTs are $\approx 5$ to $20^{\circ} \mathrm{C}$ warmer than ambient outdoor air temperatures (Lamont, 2009). However, night temperatures in HTs lacking heating systems are similar to, or can be even lower than, ambient outdoor air temperatures (Ogden and van Iersel, 2009). In addition to daily minimum and maximum temperatures, the large diurnal fluctuation in air temperature inside unheated HTs may impact bedding plant development and quality. Internode elongation increases as the difference between the day and night air temperatures (DIF) increases, and is suppressed as DIF decreases (Erwin and Heins, 1995). Excessive stem extension as a result of a large positive DIF usually warrants the application of chemical plant growth retardants.

The combination of low initial capital investment for an HT, reduction or elimination of fuel consumption for heating, and the relatively short crop time for many annuals, suggests that HTs may be a suitable alternative structure for seasonal spring bedding plant production in northern latitudes. Our research objectives were to quantify the growth and development of several bedding plant species in an unheated HT compared with a traditional $\mathrm{GH}$ at northern latitudes.

\section{Materials and methods Expt. 1}

Plant material. On 22 Mar. 2011, seedlings of 'Cooler Grape' vinca and 'Janie Deep Orange' french marigold in 512-cell size $(3.1 \mathrm{~mL}$ volume) plug trays; 'New Look' celosia, 'Super Parfait Raspberry' dianthus, 'Dreams Midnight' petunia,

\begin{tabular}{llll}
\hline $\begin{array}{l}\text { Units } \\
\text { To convert U.S. to SI, } \\
\text { multiply by }\end{array}$ & U.S. unit & SI unit & $\begin{array}{l}\text { To convert SI to U.S., } \\
\text { multiply by }\end{array}$ \\
\hline 29.5735 & $\mathrm{fl} \mathrm{oz}$ & $\mathrm{mL}$ & 0.0338 \\
0.3048 & $\mathrm{ft}$ & $\mathrm{m}$ & 3.2808 \\
2.54 & inch(es) & $\mathrm{cm}$ & 0.3937 \\
0.0254 & $\mathrm{mil}$ & $\mathrm{mm}$ & 39.3701 \\
28.3495 & $\mathrm{oz}$ & $\mathrm{g}$ & 0.0353 \\
1 & $\mathrm{ppm}$ & $\mathrm{mg} \cdot \mathrm{L}^{-1}$ & 1 \\
0.001 & $\mathrm{ppm}$ & $\mathrm{mL} \cdot \mathrm{L}^{-1}$ & 1000 \\
$\left({ }^{\circ} \mathrm{F}-32\right) \div 1.8$ & ${ }^{\circ} \mathrm{F}$ & ${ }^{\circ} \mathrm{C}$ & $\left({ }^{\circ} \mathrm{C} \times 1.8\right)+32$ \\
& & & \\
\hline
\end{tabular}

\footnotetext{
Horthech
} 
and 'Penny Lane Mix' viola in 288cell size ( $6 \mathrm{~mL}$ volume) plug trays; 'Serena Lavender' angelonia and 'Pinto Red' geranium in 128-cell size (12 mL volume) plug trays; and rooted cuttings of 'Buttery Dragon' snapdragon and 'Zion Copper Amethyst' osteospermum in 51-cell size (27.2 $\mathrm{mL}$ volume) liners were obtained from a commercial GH propagator (C. Raker \& Sons, Litchfield, MI).

These species were selected based on their commonality, commercial availability, and their variation in cold tolerance based on classification of Blanchard and Runkle (2011). The plant materials were received at both Purdue University in West Lafayette, IN (lat. $40^{\circ} \mathrm{N}$ ) and Cornell University in Ithaca, NY (lat. $42^{\circ} \mathrm{N}$ ). Seedlings and rooted cuttings were grown until transplant in a glassglazed GH under a natural photoperiod and temperature set point of 18 ${ }^{\circ} \mathrm{C}$. They were irrigated as necessary with clear water supplemented with water-soluble fertilizer (Peters Excel $21 \mathrm{~N}-2.2 \mathrm{P}-16.5 \mathrm{~K}$; Everris, Marysville, $\mathrm{OH}$ ) to provide (in $\mathrm{mg} \cdot \mathrm{L}^{-1}$ ) 150 nitrogen $(\mathrm{N}), 15$ phosphorus $(\mathrm{P}), 118$ potassium $(\mathrm{K}), 0.75$ iron (Fe), 0.19 copper $(\mathrm{Cu}), 0.19$ boron (B), 0.38 manganese $(\mathrm{Mn}), 0.38$ zinc $(\mathrm{Zn})$, and 0.075 molybdenum (Mo).

Plant culture. On l Apr. 2011, 20 seedlings or rooted cuttings of each species were transplanted into 4 -inch ( $480 \mathrm{~mL}$ volume) round containers filled with substrate composed of (by volume) $80 \%$ sphagnum peatmoss and 20\% perlite (Fafard 1P; Conrad Fafard, Agawam, MA) at each location. At Purdue, plants were hand-irrigated as necessary with clear water supplemented with $93 \%$ sulfuric acid (Ulrich Chemical, Indianapolis, IN) at $0.08 \mathrm{~mL} \cdot \mathrm{L}^{-1}$ to reduce alkalinity to $\approx 100 \mathrm{mg} \cdot \mathrm{L}^{-1}$ calcium carbonate $\left(\mathrm{CaCO}_{3}\right)$. At Cornell, plants were hand-irrigated as necessary with clear water with no added sulfuric acid as alkalinity of the municipal water source was $110 \mathrm{mg} \cdot \mathrm{L}^{-1} \mathrm{CaCO}_{3}$. Once per week, plants were irrigated with clear water supplemented with watersoluble fertilizer (Peters Excel 21N$2.2 \mathrm{P}-16.5 \mathrm{~K}$ ) to provide (in $\mathrm{mg} \cdot \mathrm{L}^{-1}$ ) $400 \mathrm{~N}, 40 \mathrm{P}, 315 \mathrm{~K}, 2.0 \mathrm{Fe}, 0.51 \mathrm{Cu}$, $0.51 \mathrm{~B}, 1.01 \mathrm{Mn}, 1.01 \mathrm{Zn}$, and 0.02 Mo. On l Apr. 2011, transplants were moved to the GH or HT environments as described below.
Greenhouse environment. At both locations, 10 plants of each species were randomly moved to glass-glazed GHs with exhaust fan and evaporative-pad cooling and radiant hot-water heating controlled by an environmental computer [Maximizer Precision 10; Priva Computers, Vineland Station, ON, Canada (at Purdue) and Operator Program; Argus Control Systems, White Rock, BC, Canada (at Cornell)]. The target $\mathrm{GH}$ day and night air temperature was $18{ }^{\circ} \mathrm{C}$.

High tunnel environment. Ten plants of each species were moved to an east-west orientated HT located in Tippecanoe, IN (Purdue) and Ithaca, NY (Cornell). At both locations, the HTs were covered with a single layer of 6-mil polyethylene. At Purdue, ventilation was provided by end-wall peak vents and roll-up side walls. Side walls were rolled down as needed during periods of high winds. During periods when air temperature was above $10{ }^{\circ} \mathrm{C}$ and winds were calm, the HT doors and vents were left open. At Cornell, ventilation was automated using an electronic motor to roll up side walls (to a $4 \mathrm{ft}$ height) when temperature inside the HT was above $29^{\circ} \mathrm{C}$ or roll down side walls when temperature inside the HT fell below $17^{\circ} \mathrm{C}$. In addition, end-wall peak vents were manually opened in mid-to-late spring when day temperatures were greater than $21^{\circ} \mathrm{C}$.

\section{Expt. 2}

Purdue University only. On 5 Apr. 2011, the temperature in the HT dropped to $-6.4^{\circ} \mathrm{C}$ resulting in severe chilling injury or death of several species. Therefore, a new set of seedlings or rooted cuttings of all species was transplanted in the GH and HT on 8 Apr. 2011, following the protocol above.

E N V I R ONMENTAL DATA collection. At Purdue, resistancebased temperature sensors (External Temperature Sensor; Spectrum Technologies, Plainfield, IL), enclosed thermocouples, and quantum sensors recorded air temperature and light intensity every $20 \mathrm{~s}$ and averages were logged every 15 min by a data logger (WatchDog Model 2475 Plant Growth Station, Spectrum Technologies). At Cornell, resistance-based temperature sensors and photosynthetically active radiation $(P A R)$ light sensors recorded air temperature and light intensity every $60 \mathrm{~s}$ and averages were logged every 10 min by a data logger (HOBO U12-012; Onset Computer Corp., Bourne, MA). Average DLI and air temperature were calculated for both locations.

Data COLLECTION AND CAlCulation. Plants were monitored daily and the date of first open flower was recorded to determine the days from experiment initiation to flower (DTF). Diameter of the first open flower was measured. At flowering, plant height was measured as the distance from the substrate surface to the tallest part of the plant. Plant width was determined as the average of two measurements: width at the widest part of the plant and at a $90^{\circ}$ angle. Plants were destructively harvested at the substrate surface to determine shoot fresh weight $(\mathrm{FW})$ and stem diameter. Shoots were dried in an oven for $3 \mathrm{~d}$ at $70{ }^{\circ} \mathrm{C}$, and shoot dry weight (DW) was recorded.

EXPERIMENTAL DESIGN AND STATISTICAL ANALYSES. The experiment was laid out in as a two-factor factorial, completely randomized design with one factor as geographic locations [L (Purdue or Cornell)] and the other factor as growing environment [E $(\mathrm{GH}$ or $\mathrm{HT})]$. At each location within each GH or HT environment, there were 10 experimental units (single plant in a container) per species and these were randomly distributed within each growing environment. For Expt. 1, analysis of variance tests (PROC GLM, SAS version 9.2; SAS Institute, Cary, NC) were conducted for the species that survived in both locations/environments (dianthus, pansy, petunia, and viola) to identify differences in the measured parameters based on location, environment, or their interaction. When a significant $\mathrm{L}$ by $\mathrm{E}$ interaction was found, mean separation comparisons were conducted using Tukey's honestly significant difference test at $\alpha=0.05$. For species that did not survive in the Purdue HT environment in Expt. I (angelonia, celosia, geranium, lobelia, french marigold, osteospermum, and vinca), mean separation comparisons were conducted using Tukey's honestly significant difference test at $\alpha=0.05$ to compare measured parameters 
Table 1. Location, growing month, daily light integral (DLI), and air temperature for 11 bedding plants grown in a climatecontrolled greenhouse (GH) or high tunnel (HT) in Spring 2011 at both Cornell University (Ithaca, NY) and Purdue University (West Lafayette, IN). Average temperature and DLI data are means of average values logged every 10 or 15 min at Cornell and Purdue, respectively.

\begin{tabular}{|c|c|c|c|c|c|c|c|c|}
\hline \multirow[b]{3}{*}{ Month } & \multirow{2}{*}{\multicolumn{2}{|c|}{ Avg daily temp $\left[\text { mean } \pm \mathrm{SD}\left({ }^{\circ} \mathrm{C}\right)\right]^{\mathrm{z}}$}} & \multicolumn{4}{|c|}{ Temp $\left({ }^{\circ} \mathbf{C}\right)$} & & \\
\hline & & & \multicolumn{2}{|c|}{ Minimum } & \multicolumn{2}{|c|}{ Maximum } & \multicolumn{2}{|c|}{ Avg DLI $\left[\right.$ mean $\left.\pm S D\left(\mathrm{~mol} \cdot \mathrm{m}^{-2} \cdot \mathrm{d}^{-1}\right)\right]$} \\
\hline & GH & HT & $\overline{\mathrm{GH}}$ & HT & $\overline{\text { GH }}$ & HT & GH & HT \\
\hline \multicolumn{9}{|c|}{ Purdue } \\
\hline April & $18.7 \pm 2.6$ & $11.2 \pm 4.2$ & 16.6 & -6.4 & 30.8 & 28.6 & $11.8 \pm 5.7$ & $21.1 \pm 5.4$ \\
\hline May & $20.4 \pm 3.0$ & $16.8 \pm 5.7$ & 13.3 & 0.40 & 29.3 & 33.9 & $11.4 \pm 3.0$ & $23.4 \pm 5.7$ \\
\hline \multicolumn{9}{|c|}{ Cornell } \\
\hline May & $20.1 \pm 3.6$ & $20.4 \pm 10.4$ & 16.0 & 1.3 & 35.1 & 54.1 & $10.2 \pm 4.1$ & $20.1 \pm 5.1$ \\
\hline
\end{tabular}

${ }^{\mathrm{z}}\left(1.8 \times{ }^{\circ} \mathrm{C}\right)+32={ }^{\circ} \mathrm{F}$.

between Cornell GH, Cornell HT, and Purdue GH. For Expt. 2, analysis of variance tests (PROC GLM, SAS version 9.2) were conducted to identify differences in the measured parameters based on $\mathrm{E}$.

\section{Results and discussion}

EFFECT OF LOCATION AND GROWING ENVIRONMENT ON TEMPERATURE AND LIGHT CONDITIONS. As expected, the unheated HT provided a cooler growing environment than $\mathrm{GHs}$ heated to $18{ }^{\circ} \mathrm{C}$ especially during the month of April (Table 1). At Purdue, the average daily temperature in the unheated HT was 7.5 and $3.6^{\circ} \mathrm{C}$ less than the heated GH in April and May, respectively. At Cornell, the HT average daily temperature was $4.5^{\circ} \mathrm{C}$ less than and $0.3^{\circ} \mathrm{C}$ greater than the $\mathrm{GH}$ in April and May, respectively. As can be noted by the high standard deviation of temperatures as well as the minimum and maximum temperatures, the HT environment is much more variable with regard to daily temperature extremes and fluctuations (Fig. 1). The maximum temperatures at the Cornell and Purdue HTs appear quite extreme $\left(48.9\right.$ and $58.1^{\circ} \mathrm{C}$ in April, respectively). However, these events were transitory and did not last more than $10 \mathrm{~min}$. Visual plant damage was not evident following these events. The cause of the Cornell event appears to be malfunction of the thermostat and/or electronic motor to roll up the side walls. This demonstrates one risk when growing in HTs vs. a more controlled $\mathrm{GH}$ environment. One positive effect of the HT environment at both Cornell and Purdue was an increased DLI (Table 1 ). This may be explained



Fig. 1. Purdue University (West Lafayette, IN) and Cornell University (Ithaca, NY) high tunnel and greenhouse daily minimum (Min) and maximum (Max) temperatures from 1 Apr. to 1 June $2011 ;\left(1.8 \times{ }^{\circ} \mathrm{C}\right)+32={ }^{\circ} \mathrm{F}$.

by the minimal structure and superstructures in the HT, which meant less shading as compared with the $\mathrm{GH}$.

EFFECT OF LOCATION ON FINISHING TIME. A cold temperature event occurred one night in early April a few days after planting. This led to an air temperature recording of $-3.2^{\circ} \mathrm{C}$ at Cornell and $-6.4^{\circ} \mathrm{C}$ at Purdue (Table
1). After this temperature event, the majority of the angelonia, celosia, geranium, lobelia, french marigold, osteospermum, and vinca grown in the HT died, while dianthus, viola, petunia, and snapdragon survived (Table 2). Therefore, these species were removed from Expt. 1 at Purdue. Blanchard and Runkle (2011) identified three categories of cold 
Research Reports

Table 2. Effect of geographic location (L) and growing environment [E; greenhouse (GH) or high tunnel (HT)] on days to flower (DTF) from transplant and other growth attributes measured at DTF. The 10 bedding plants were transplanted and moved to the corresponding finishing environment on 1 Apr. 2011 at Cornell University (Ithaca, NY) and Purdue University (West Lafayette, IN).

\begin{tabular}{|c|c|c|c|c|c|c|c|}
\hline Location & $\begin{array}{c}\text { Growing } \\
\text { environment }\end{array}$ & $\begin{array}{c}\text { Shoot fresh } \\
\text { wt }(\mathrm{g})^{\mathrm{z}}\end{array}$ & $\begin{array}{c}\text { Shoot dry } \\
\text { wt (g) }\end{array}$ & $\mathrm{Ht}(\mathrm{cm})^{\mathrm{z}}$ & Width $(\mathrm{cm})$ & $\begin{array}{c}\text { Flower } \\
\text { diam }(\mathrm{cm})\end{array}$ & $\operatorname{DTF}(\mathrm{d})$ \\
\hline \multicolumn{8}{|c|}{ Angelonia } \\
\hline Purdue & $\mathrm{GH}$ & $31.4^{\mathrm{y}} \mathrm{a}$ & $4.2 \mathrm{a}$ & $30.2 \mathrm{a}$ & $25.5 \mathrm{a}$ & $2.0 \mathrm{a}$ & $34.2 \mathrm{~b}$ \\
\hline & $\mathrm{HT}$ & $-^{x}$ & - & - & - & - & - \\
\hline \multirow[t]{2}{*}{ Cornell } & $\mathrm{GH}$ & $21.1 \mathrm{~b}$ & $2.8 \mathrm{~b}$ & $28.2 \mathrm{a}$ & $18.5 \mathrm{~b}$ & $2.2 \mathrm{a}$ & $32.9 \mathrm{~b}$ \\
\hline & $\mathrm{HT}$ & $15.3 \mathrm{c}$ & $2.4 \mathrm{~b}$ & $15.7 \mathrm{~b}$ & $15.3 \mathrm{~b}$ & $3.7 \mathrm{a}$ & $45.0 \mathrm{a}$ \\
\hline \multirow[t]{2}{*}{ Purdue } & $\mathrm{GH}$ & $45.6 \mathrm{a}$ & $4.7 \mathrm{a}$ & $24.9 \mathrm{~b}$ & $26.0 \mathrm{a}$ & $2.3 \mathrm{a}$ & $35.2 \mathrm{c}$ \\
\hline & $\mathrm{HT}$ & - & - & - & - & - & - \\
\hline \multirow[t]{2}{*}{ Cornell } & $\mathrm{GH}$ & $44.6 \mathrm{a}$ & $4.9 \mathrm{a}$ & $30.2 \mathrm{a}$ & $20.8 \mathrm{~b}$ & $2.6 \mathrm{a}$ & $46.9 \mathrm{~b}$ \\
\hline & $\mathrm{HT}$ & $26.3 \mathrm{~b}$ & $2.8 \mathrm{~b}$ & $15.8 \mathrm{c}$ & $13.8 \mathrm{c}$ & $1.9 \mathrm{a}$ & $55.5 \mathrm{a}$ \\
\hline \multicolumn{8}{|c|}{ Dianthus } \\
\hline & $\mathrm{HT}$ & 55.5 & 9.1 & 17.1 & $20.8 \mathrm{a}$ & 4.6 & 57.9 \\
\hline $\mathrm{L}$ & & $\mathrm{NS}^{\mathrm{w}}$ & NS & NS & * & NS & $* * *$ \\
\hline $\mathrm{E}$ & & $* * *$ & $* * *$ & * & NS & $* *$ & $* * *$ \\
\hline $\mathrm{L} \times \mathrm{E}$ & & NS & NS & NS & $* * *$ & NS & NS \\
\hline \multicolumn{8}{|c|}{ Geranium } \\
\hline \multirow[t]{2}{*}{ Purdue } & $\mathrm{GH}$ & $96.1 \mathrm{a}$ & $12.3 \mathrm{ab}$ & $17.5 \mathrm{c}$ & $22.5 \mathrm{~b}$ & $4.5 \mathrm{~b}$ & $49.8 \mathrm{~b}$ \\
\hline & $\mathrm{HT}$ & - & - & - & - & - & - \\
\hline \multirow[t]{2}{*}{ Cornell } & $\mathrm{GH}$ & $86.9 \mathrm{a}$ & $14.1 \mathrm{a}$ & $32.5 \mathrm{a}$ & $29.4 \mathrm{a}$ & $4.8 \mathrm{a}$ & $61.6 \mathrm{a}$ \\
\hline & $\mathrm{HT}$ & $65.8 \mathrm{~b}$ & $9.8 \mathrm{~b}$ & $24.0 \mathrm{~b}$ & $20.1 \mathrm{~b}$ & $4.1 \mathrm{c}$ & $60.2 \mathrm{a}$ \\
\hline \multicolumn{8}{|c|}{ Lobelia } \\
\hline & $\mathrm{HT}$ & - & - & - & - & - & - \\
\hline \multirow[t]{2}{*}{ Cornell } & $\mathrm{GH}$ & $14.8 \mathrm{~b}$ & $1.1 \mathrm{~b}$ & $11.3 \mathrm{a}$ & $15.9 \mathrm{a}$ & $4.5 \mathrm{ab}$ & $20.5 \mathrm{~b}$ \\
\hline & HT & $10.5 \mathrm{~b}$ & $1.2 \mathrm{~b}$ & $9.0 \mathrm{~b}$ & $11.5 \mathrm{~b}$ & $3.6 \mathrm{~b}$ & $29.5 \mathrm{a}$ \\
\hline \multicolumn{8}{|c|}{ Osteospermum } \\
\hline \multirow[t]{2}{*}{ Purdue } & $\mathrm{GH}$ & $44.4 \mathrm{~b}$ & $5.3 \mathrm{~b}$ & $22.8 \mathrm{a}$ & $24.5 \mathrm{a}$ & $5.7 \mathrm{a}$ & $27.3 \mathrm{~b}$ \\
\hline & $\mathrm{HT}$ & - & - & - & - & - & - \\
\hline \multirow[t]{2}{*}{ Cornell } & $\mathrm{GH}$ & $35.9 \mathrm{~b}$ & $3.8 \mathrm{c}$ & $23.1 \mathrm{a}$ & $16.9 \mathrm{~b}$ & $5.4 \mathrm{ab}$ & $35.0 \mathrm{ab}$ \\
\hline & $\mathrm{HT}$ & $67.6 \mathrm{a}$ & $8.5 \mathrm{a}$ & $18.7 \mathrm{~b}$ & $17.5 \mathrm{~b}$ & $5.0 \mathrm{~b}$ & $42.6 \mathrm{a}$ \\
\hline \multicolumn{8}{|c|}{ Viola } \\
\hline Purdue & $\mathrm{GH}$ & 10.3 & $1.0 \mathrm{~b}$ & 8.8 & 13.8 & 3.3 & 12.2 \\
\hline & $\mathrm{HT}$ & 8.9 & $0.97 \mathrm{~b}$ & 6.4 & 10.3 & 3.1 & 12.3 \\
\hline Cornell & $\mathrm{GH}$ & 12.4 & $1.7 \mathrm{a}$ & 12.6 & 15.8 & 3.5 & 17.6 \\
\hline & $\mathrm{HT}$ & 10.3 & $0.93 \mathrm{~b}$ & 9.7 & 13.5 & 3.7 & 17.9 \\
\hline $\mathrm{L}$ & & NS & * & $* * *$ & * & $* * *$ & $* *$ \\
\hline $\mathrm{E}$ & & NS & ** & $* * *$ & ** & NS & NS \\
\hline $\mathrm{L} \times \mathrm{E}$ & & NS & ** & NS & NS & NS & NS \\
\hline
\end{tabular}

(Continued on next page) 
Table 2. (Continued) Effect of geographic location (L) and growing environment [E; greenhouse (GH) or high tunnel (HT)] on days to flower (DTF) from transplant and other growth attributes measured at DTF. The 10 bedding plants were transplanted and moved to the corresponding finishing environment on 1 Apr. 2011 at Cornell University (Ithaca, NY) and Purdue University (West Lafayette, IN).

\begin{tabular}{|c|c|c|c|c|c|c|c|}
\hline Location & $\begin{array}{c}\text { Growing } \\
\text { environment }\end{array}$ & $\begin{array}{c}\text { Shoot fresh } \\
\text { wt }(\mathbf{g})^{\mathrm{z}}\end{array}$ & $\begin{array}{l}\text { Shoot dry } \\
\text { wt (g) }\end{array}$ & $\mathrm{Ht}(\mathrm{cm})^{\mathrm{z}}$ & Width $(\mathrm{cm})$ & $\begin{array}{c}\text { Flower } \\
\operatorname{diam}(\mathrm{cm})\end{array}$ & $\operatorname{DTF}(\mathrm{d})$ \\
\hline \multicolumn{8}{|c|}{ Petunia } \\
\hline & $\mathrm{HT}$ & 79.9 & 7.7 & $14.1 \mathrm{c}$ & 25.4 & $7.9 \mathrm{~b}$ & 34.8 \\
\hline \multirow[t]{2}{*}{ Cornell } & $\mathrm{GH}$ & 85.5 & 6.7 & $23.0 \mathrm{a}$ & 25.3 & $9.5 \mathrm{a}$ & 34.1 \\
\hline & $\mathrm{HT}$ & 73.2 & 6.1 & $8.5 \mathrm{~d}$ & 20.0 & $7.6 \mathrm{~b}$ & 42.1 \\
\hline $\mathrm{L} \times \mathrm{E}$ & & NS & NS & $* * *$ & NS & $* *$ & NS \\
\hline \multicolumn{8}{|c|}{ Snapdragon } \\
\hline \multirow[t]{2}{*}{ Purdue } & $\mathrm{GH}$ & $47.6 \mathrm{a}$ & $6.1 \mathrm{~b}$ & 24.2 & 20.5 & $3.4 \mathrm{~b}$ & 29.8 \\
\hline & $\mathrm{HT}$ & $73.1 \mathrm{~b}$ & $9.8 \mathrm{a}$ & 18.9 & 15.3 & $3.1 \mathrm{~b}$ & 42.3 \\
\hline $\mathrm{L} \times \mathrm{E}$ & & $* * *$ & $* * *$ & NS & NS & * & NS \\
\hline \multicolumn{8}{|c|}{ Vinca } \\
\hline \multirow[t]{2}{*}{ Purdue } & $\mathrm{GH}$ & $28.2 \mathrm{a}$ & $3.6 \mathrm{a}$ & $16.2 \mathrm{a}$ & $13.6 \mathrm{a}$ & $4.4 \mathrm{a}$ & $49.3 \mathrm{~b}$ \\
\hline & $\mathrm{HT}$ & - & - & - & - & - & - \\
\hline \multirow[t]{2}{*}{ Cornell } & $\mathrm{GH}$ & $14.6 \mathrm{~b}$ & $2.1 \mathrm{~b}$ & $14.4 \mathrm{a}$ & $16.3 \mathrm{a}$ & $3.3 \mathrm{a}$ & $53.1 \mathrm{~b}$ \\
\hline & $\mathrm{HT}$ & $17.9 \mathrm{~b}$ & $2.8 \mathrm{ab}$ & $13.7 \mathrm{a}$ & $13.6 \mathrm{a}$ & $4.0 \mathrm{a}$ & $59.2 \mathrm{a}$ \\
\hline
\end{tabular}

${ }^{\mathrm{z}} 1 \mathrm{~g}=0.0353 \mathrm{oz}, 1 \mathrm{~cm}=0.3937$ inch.

yWithin-column means followed by different lower-case letters are significantly different by Tukey's honestly significant difference test at $P \leq 0.05$.

'Indicates data are not available, plants from this treatment died during a low temperature event in early April.

"Two-way analysis of variance for the main effects and interactions of $\mathrm{L}$ and $\mathrm{E}$. Ns, ${ }^{*},{ }^{*},{ }^{* *}$ Not significant or significantly different from control at $P \leq 0.05,0.01,0.001$, respectively.

'Lobelia plugs were in flower at transplant, therefore DTF was not recorded.

tolerance based on base temperature $\left(\mathrm{T}_{\mathrm{b}}\right)$ : cold tolerant $\left(\mathrm{T}_{\mathrm{b}} \leq 4^{\circ} \mathrm{C}\right)$, cold temperate $\left(\mathrm{T}_{\mathrm{b}}=5-7^{\circ} \mathrm{C}\right)$, or cold sensitive $\left(T_{b} \geq 8{ }^{\circ} \mathrm{C}\right)$. Of those species that survived, dianthus, viola, and snapdragon are considered cold tolerant, while petunia is classified as cold temperate. Alternatively, for those crops that died, angelonia, celosia, and vinca are cold sensitive, geranium, lobelia, and french marigold are cold-temperate crops, and osteospermum is a cold-tolerant crop. Cold-sensitive crops may not be suitable candidates for unheated HT production early in the spring season. Alternatively, exposing cold-temperate or cold-tolerant plants to cool temperatures ("hardening off") preceding placement into unheated HTs may reduce the risk of death on exposure to cold temperatures. Additionally, providing some marginal protection such as floating rowcovers may mitigate some of the risk with these species.
It is well established that temperature controls the rate of plant development, including time to unfold a leaf and time to flower (Roberts and Summerfield, 1987). However, much of this research has been done in the $\mathrm{GH}$ or controlled environment chambers where average daily temperature conditions do not fluctuate as greatly as in HTs.

When comparing the species that survived the 1 Apr. planting date at Purdue (dianthus, viola, petunia, and snapdragon) to their Cornell counterparts, there were some differences in DTF. For dianthus, there was about an 8-d delay in DTF at the Cornell HT as compared with Purdue (Table 2). For viola, the only significant difference was that plants at Cornell flowered about $6 \mathrm{~d}$ later than those grown at Purdue, regardless of the environment. For petunia, Cornell HT plants flowered about $7 \mathrm{~d}$ later than their Purdue counterparts. When comparing the environmental data, it appears that a greater DLI at the Purdue HT may be the primary explanation. Both petunia and viola are reported to flower earlier developmentally under increasing DLI (Oh et al., 2010) as they exhibit a facultative irradiance response. For snapdragon, DTF of HT plants were similar between both locations.

EFFECT OF GROWING ENVIRONMENT ON FINISHING TIME. At Cornell, HT-grown geranium, osteospermum, and viola had a similar DTF as GH-grown plants (Table 2). However, at Cornell, a delay in DTF was observed for HT-grown angelonia (12 d), celosia (9 d), dianthus $(8 \mathrm{~d})$, french marigold $(9 \mathrm{~d})$, petunia (8 d), snapdragon (20 d), and vinca (6 d) (Table 2). For Purdue, a similar trend was observed for DTFs for the 1 Apr. transplant date, with some delays in the HT- vs. GH-grown plants. Dianthus and snapdragon DTF were delayed by 4 and $13 \mathrm{~d}$, respectively, when grown in an HT, while there 
were no differences for petunia and viola. For the 8 Apr. transplant date at Purdue, there was very little effect of growing environment on DTF; a delay in DTF was observed only in HT-grown geranium (3 d) and osteospermum (7 d) compared with plants in the GH (Table 3).

EFFECT OF GROWING ENVIRONMENT ON PLANT QUALITY. Shoot FW and DW, plant height and width, and flower diameter were recorded to determine the overall plant quality for this experiment. At Cornell, the DW of celosia, geranium, and viola were significantly greater in the $\mathrm{GH}$ than HT, while DW of dianthus and osteospermum were greater in the HT (Table 2). Dry weight of angelonia, lobelia, french marigold, petunia, snapdragon, and vinca was unaffected by growing environment. At Purdue for 1 Apr. plants, dianthus and snapdragon had a greater DW in the HT than the $\mathrm{GH}$, whereas viola and petunia were unaffected by growing environment. The increase in DW for some plants in the HT environment may be due to greater DLI and longer finish time as compared with their $\mathrm{GH}$ counterparts. For the $8 \mathrm{Apr}$. transplant date at Purdue, the DW of HT angelonia, celosia, dianthus, french marigold, osteospermum, snapdragon, and vinca plants was greater than the GH-grown plants (Table 3). However, geranium and lobelia plants had a greater DW in the GH, and viola and petunia were unaffected by growing environment. These results suggest that reductions in DW from the HT environment could be largely avoided by planting later in the spring so as to avoid low night temperature events.

In general, HT-grown plants were similar or shorter than those grown in the GH. Angelonia, celosia, and petunia plants exhibited the most dramatic height differences at Cornell, as HT plants were about half as tall as GH plants. Initially, this challenged our concern about the potential for excessive stem elongation as a result of large diurnal differences in the air temperature and, therefore, a large positive DIF (Fig. 1). However, on closer investigation of our air temperature data, we found that often the coldest period was around the predawn time period. This temperature regime is similar to a DIP or DROP, where a negative DIF is created by reducing $\mathrm{GH}$ air temperatures in the morning for several hours (Erwin and Heins, 1995). Therefore, we believe this resulted in stem elongation similar to or less than those grown in the GH. Average daily temperature was also lower in the HT than the $\mathrm{GH}$ during much of the growing season. In addition to temperature, we also believe that the DLI contributed to large differences in plant growth. While the effects of DLI on stem elongation vary among species, it is common for stem elongation to be reduced under high DLIs (Blanchard et al., 2011). In our study, the HT DLIs were generally two times greater compared with the GH DLIs and can help explain why there was not excessive stem elongation in the HT. We could not find direct comparisons in the literature of light transmission in a $\mathrm{GH}$ vs. a nearby sited HT. In New Jersey, the percent transmission of $P A R$ in HTs at two locations averaged $76 \%$ (Both et al., 2007), and a study in a Michigan HT reported $74 \%$ PAR transmission (Lang, 2009). Giacomelli and Roberts (1993) reported that percent transmission of $P A R$ at crop canopy as measured in four different $\mathrm{GH}$ structures varied from $45 \%$ to $56 \%$.

There were subtle differences of growing environment on flower diameter. At Purdue for the 1 Apr. transplant date, GH dianthus had larger flowers than HT plants. At Cornell GH, geranium, french marigold, petunia, and snapdragon had larger flowers than HT plants. High tunnel angelonia had larger flowers than their $\mathrm{GH}$ counterparts. For the 8 Apr. transplant date at Purdue, only petunia exhibited a significant growing environment response on flower diameter; flower diameter of HT plants was smaller than $\mathrm{GH}$ plants.

Potential Benefits associated WITH HIGH TUNNEL-GROWN SPRING BEDDING PLANTS. One of the primary advantages of using HTs to finish spring bedding plants is the reduction in energy costs associated with actively heated GHs. Further, HTs represent a lower capital investment cost as compared with conventional GHs. They may enable spring bedding plant growers to meet their seasonal peak space demand without greater investment costs while still providing some protection compared with the outside environment. In our current work, we also determined that finishing bedding plants in HTs led to improvements in measures of plant quality for some crops, such as shorter, more compact plants than $\mathrm{GH}$-grown counterparts. This could reduce the need for application of chemical plant growth regulators.

Potential Risks associated WITH HIGH TUNNEL-GROWN SPRING BEDDING PLANTS. While finishing spring annuals in an unheated HT presents an opportunity to reduce input costs associated with a heated environment, there are some clear challenges that must be weighed when assessing this production method. First, the risk of harmful or lethal outdoor temperatures with respect to plant growth clearly exists. The effects of this risk were observed in the first planting at Purdue. One night of $-6^{\circ} \mathrm{C}$ resulted in the death of several crops. There are several strategies available to growers that may help abate this risk. First, growers can restrict production in unheated structures to cold-tolerant crops such as viola, dianthus, or petunia. Employing an additional source of frost protection such as a floating rowcover may provide adequate protection for crops against harmful or lethal temperatures. Another strategy could be to use unit heaters or other inexpensive heating sources in a minimal way, only to avoid dangerously low night temperatures. In our experiment, plants were not acclimated to cool temperatures before moving to the HT environment. Cold acclimation or "hardening" of plants in the GH before the transition to the HT may be useful to avoid the risk of low temperature events. More research should be done to characterize the effect of rowcover usage, planting date, and cold acclimation on spring bedding plants finished in HTs.

An additional challenge with HTs is accurate crop scheduling. Between a $T_{b}$ and optimal temperature, the rate of plant development is linearly related to temperature (Roberts and Summerfield, 1987). Growers frequently use this relationship to their advantage and can lower or raise $\mathrm{GH}$ air temperature set points to increase or decrease the rate of plant development to hasten or slow plant development to meet market dates. The use of unheated HTs 
Table 3. Effect of greenhouse (GH) or high tunnel (HT) environment (E) on days to flower (DTF) from transplant and other growth attributes measured at DTF for the 10 bedding plants transplanted and moved to the corresponding finishing environment on 8 Apr. 2011 at Purdue University (West Lafayette, IN).

\begin{tabular}{|c|c|c|c|c|c|c|}
\hline $\begin{array}{l}\text { Growing } \\
\text { environment }\end{array}$ & $\begin{array}{l}\text { Shoot fresh } \\
\text { wt }(g)^{z}\end{array}$ & $\begin{array}{l}\text { Shoot dry } \\
\text { wt (g) }\end{array}$ & $\mathrm{Ht}(\mathrm{cm})^{\mathrm{z}}$ & Width $(\mathrm{cm})$ & $\begin{array}{c}\text { Flower } \\
\operatorname{diam}(\mathrm{cm})^{\mathrm{z}}\end{array}$ & $\operatorname{DTF}(\mathrm{d})$ \\
\hline \multicolumn{7}{|c|}{ Angelonia } \\
\hline $\mathrm{GH}$ & 15.6 & 2.1 & 26.6 & 16.3 & 2.2 & 28.7 \\
\hline $\mathrm{HT}$ & 16.1 & 2.4 & 20.3 & 11.7 & 2.1 & 31.7 \\
\hline $\mathrm{E}$ & $\mathrm{NS}^{\mathrm{y}}$ & ** & $* * *$ & $* * *$ & NS & NS \\
\hline \multicolumn{7}{|c|}{ Celosia } \\
\hline $\mathrm{HT}$ & 34.8 & 4.1 & 19.5 & 19.0 & 2.3 & 27.2 \\
\hline $\mathrm{E}$ & NS & * & NS & $* *$ & NS & NS \\
\hline \multicolumn{7}{|c|}{ Dianthus } \\
\hline $\mathrm{GH}$ & 33.3 & 4.6 & 18.6 & 15.7 & 4.7 & 46.0 \\
\hline $\mathrm{HT}$ & 57.1 & 8.7 & 15.9 & 17.7 & 4.4 & 44.2 \\
\hline $\mathrm{GH}$ & 113.2 & 14.7 & 20.1 & 26.4 & 4.3 & 53.7 \\
\hline HT & 99.1 & 12.9 & 17.2 & 19.0 & 4.1 & 56.8 \\
\hline $\mathrm{E}$ & $* *$ & * & ** & $* * *$ & NS & $* * *$ \\
\hline \multicolumn{7}{|c|}{ Lobelia } \\
\hline $\mathrm{GH}$ & 24.4 & 3.4 & 22.7 & 33.5 & 2.2 & $-^{x}$ \\
\hline $\mathrm{HT}$ & 13.8 & 2.6 & 17.2 & 19.0 & 2.1 & - \\
\hline $\mathrm{E}$ & $* * *$ & $* * *$ & $* * *$ & $* * *$ & NS & - \\
\hline \multicolumn{7}{|c|}{ French marigold } \\
\hline $\mathrm{GH}$ & 11.4 & 1.0 & 9.3 & 13.3 & 4.6 & 17.0 \\
\hline \multicolumn{7}{|c|}{ Viola } \\
\hline $\mathrm{GH}$ & 10.0 & 1.0 & 8.6 & 13.8 & 3.6 & 14.3 \\
\hline HT & 8.7 & 1.1 & 6.7 & 10.2 & 3.5 & 14.5 \\
\hline $\mathrm{E}$ & NS & NS & * & * & NS & NS \\
\hline \multicolumn{7}{|c|}{ Petunia } \\
\hline $\mathrm{GH}$ & 58.1 & 5.5 & 14.8 & 23.1 & 8.5 & 29.5 \\
\hline HT & 63.9 & 5.8 & 11.0 & 18.9 & 7.2 & 30.0 \\
\hline $\mathrm{E}$ & * & NS & $* * *$ & ** & * & NS \\
\hline \multicolumn{7}{|c|}{ Snapdragon } \\
\hline $\mathrm{GH}$ & 40.4 & 5.8 & 22.2 & 20.6 & 3.0 & 31.2 \\
\hline $\mathrm{HT}$ & 54.3 & 7.3 & 17.7 & 14.7 & 3.2 & 34.3 \\
\hline $\mathrm{E}$ & $* * *$ & $* * *$ & $* *$ & $\star * *$ & NS & NS \\
\hline \multicolumn{7}{|c|}{ Vinca } \\
\hline $\mathrm{GH}$ & 19.9 & 2.2 & 14.9 & 13.1 & 4.3 & 44.8 \\
\hline HT & 27.9 & 3.9 & 16.4 & 16.3 & 4.1 & 45.0 \\
\hline $\mathrm{E}$ & $* * *$ & $* * *$ & $\star *$ & $* * *$ & NS & NS \\
\hline
\end{tabular}


removes the ability to control temperature beyond passive cooling via ventilation through side and end walls.

While we acknowledge the risk of finishing spring bedding plant crops in an unheated environment, there is a potential for gains in profitability for producers because of the lower capital and energy costs of HTs as compared with conventional GHs. More work is necessary to quantify the economic costs of finishing spring bedding plants in an $\mathrm{HT}$ vs. a $\mathrm{GH}$ including a risk assessment.

\section{Conclusions}

In this research, we investigated the suitability of unheated HTs for finishing several common bedding plant species in the spring at two USDA Hardiness Zone 5 locations. Based on our findings, the suitability of bedding crops should be examined on a cultivar- and species-specific basis. As well, local conditions must also be considered. At Cornell, all 10 species survived in the unheated HT environment when moved there on 1 Apr. 2011. The lowest recorded temperature at the Cornell HT was $-3.2^{\circ} \mathrm{C}$. It is interesting to note that the cold-sensitive species angelonia, celosia, and vinca survived this shortterm cold exposure. A significant delay in flowering was found for most of 10 species when comparing HTgrown plants to those grown in the heated GH. At Purdue, for the 8 Apr. 2011 transplant date, three species exhibited a delay in DTF as compared with GH plants. Thus for 2011 at Purdue, delaying the HT transplant date was an effective method for reducing plant mortality and reducing delays in DTF because of the cold temperature environment of the HT. We found the effects of finishing environment on shoot DW also varied by crop species with the high light and low temperatures of the HT environment being favorable toward DW accumulation of some species but not others. Regarding plant height, the HT environment generally led to height being the same as or shorter than the heated GH. Our findings can be used by producers attempting to choose spring bedding plant crops suitable for finishing in unheated HTs in their own operations. Additional work should be done on the use of HTs for bedding plants in other geographic locations and with other bedding plant crops to expand the knowledge base on this production method.

\section{Literature cited}

Armitage, A.M. and J.M. Laushman. 2003. Specialty cut flowers. 2 nd ed. Timber Press, Portland, OR.

Blanchard, M. and E. Runkle. 2011. Temperature, p. 67-81. In: J. Nau (ed.). Ball redbook. Vol. II. 18th ed. Ball Publ., West Chicago, IL.

Blanchard, M.G., E.S. Runkle, and P.R. Fisher. 2011. Modeling plant morphology and development of petunia in response to temperature and photosynthetic daily light integral. Sci. Hort. 129:313-320.

Both, A.J., E. Reiss, J.F. Sudal, K.E. Holmstrom, C.A. Wyenandt, W.L. Kline, and S.A. Garrison. 2007. Evaluation of a manual energy curtain for tomato production in high tunnels. Hort Technology 17:467-472.
Brumfield, R. 2007. Dealing with rising energy costs. Greenhouse Prod. News 17:24-31.

Byczynski, L. 2008. The flower farmer. Chelsea Green Publ., White River Junction, VT.

Erwin, J.E. and R.D. Heins. 1995. Thermomorphogenic responses in stem and leaf development. HortScience 30:940949.

Giacomelli, G.A. and W.J. Roberts. 1993. Greenhouse covering systems. HortTechnology 3:50-58.

Lamont, W.J. 2009. Overview of the use of high tunnels worldwide. HortTechnology 19:25-29.

Lang, G.A. 2009. High tunnel tree fruit production: The final frontier? HortTechnology 19:50-55.

Langton, A., C. Plackett, and H. Kitchener. 2006. Energy saving in poinsettia production. Hort. Dev. Council Factsheet 7:1-12.

Ogden, A.B. and M.W. van Iersel. 2009. Southern highbush blueberry production in high tunnels: Temperatures, development, yield, and fruit quality during the establishment years. HortScience 44:1850-1856.

Oh, W., E.S. Runkle, and R.M. Warner. 2010. Timing and duration of supplemental lighting during the seedling stage influence quality and flowering in petunia and viola. HortScience 45:13321337.

Roberts, E.H. and R.J. Summerfield. 1987. Measurement and prediction of flowering in annual crops, p. 17-50. In: J.G. Atherton (ed.). Manipulation of flowering. Butterworths, London, UK.

Wien, H.C. 2009. Floral crop production in high tunnels. HortTechnology 19:5660 . 